
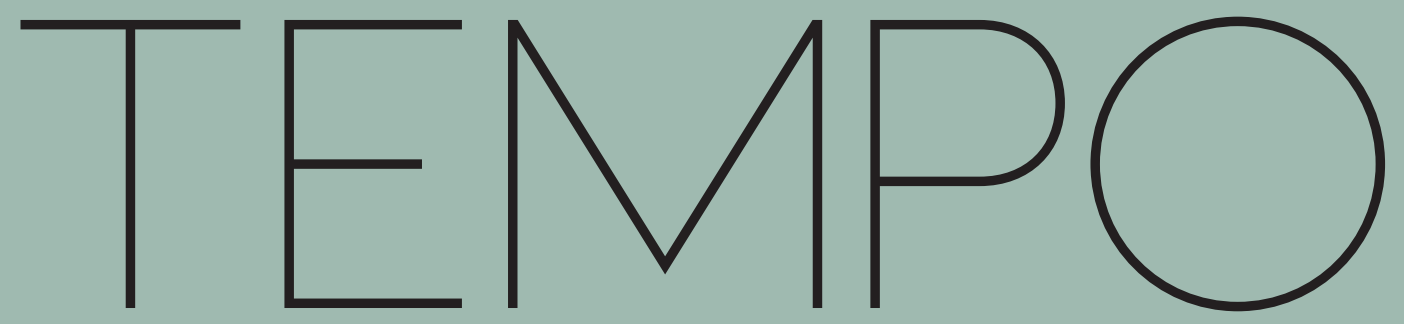

A QUARTERLY REVIEW OF NEW MUSIC

EDITORIAL: VERY HEAVEN

OPENING OFFER OR CONTRACTUAL OBLIGATION?

ON THE PRESCRIPTIVE FUNCTION OF NOTATION

IN MUSIC TODAY

CHRISTOPHER FOX

JOANNA BAILIE: STRANGE PARALLEL MUSIC

STEPHANIE POWER

RIGHT AND WRONG: THE MUSIC OF

ANDREW HAMILTON

DONAL SARSFIELD

PERFORMING THE PATRON: BETTY FREEMAN AND

THE AVANT-GARDE

JAKE JOHNSON

ALONG THE GRAIN: THE MUSIC OF

CASSANDRA MILLER

JAMES WEEKS

REVIEWS: FIRST PERFORMANCES, CDs \& DVDs, AND BOOKS

PROFILE: WINRICH HOPP 


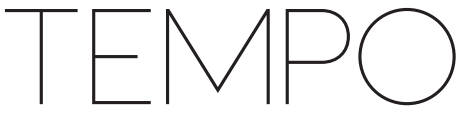

EDITOR Bob Gilmore

tempoeditor@cambridge.org

REVIEWS EDITOR Juliet Fraser

temporeviews@cambridge.org

ADVERTISING

Email (UK and rest of the world)

ad_sales@cambridge.org

Email (US) USAdsales@cambridge.org

SUBSCRIPTION ENQUIRIES

Tel: 01223326070

Email: journals@cambridge.org

EMERITUS EDITOR

Calum MacDonald

ADVISORY BOARD

Amy C. Beal

University of California, Santa Cruz, USA

Davinia Caddy

University of Auckland, New Zealand

Jonathan Cross

University of Oxford, UK

Mark Delaere

KU Leuven, Belgium

Christopher Fox

Brunel University, UK

Kyle Gann

Bard College, USA

Gisela Gronemeyer

Cologne, Germany

Peter Hill

University of Sheffield, UK

Nicholas Jones

Cardiff University, UK

Robin Maconie

Dannevirke, New Zealand

Gerard McBurney

Chicago Symphony Orchestra, USA

François-Bernard Mâche

Paris, France

Olivia Mattis

Huntingdon, New York, USA

David Metzer

University of British Columbia, Canada

Tim Rutherford-Johnson

London, UK

Howard Skempton

Leamington Spa, UK

Arnold Whittall

King's College London, UK

Rachel Beckles Willson

University of London, UK

\section{Mission Statement}

As a 'Quarterly Review of New Music', TEMPO exists to document the international new music scene while contributing to, and stimulating, current debates therein. Its emphasis is on musical developments in our own century, as well as on music that came to prominence in the later twentieth century that has not yet received the attention it deserves.

\section{Subscriptions}

Tempo (ISSN 0040-2982) is published four times a year in January, April, July and October. Four parts form a volume. The subscription price for volume 68 (Nos. 267-270), which includes delivery by air where appropriate (but excluding VAT) is £101 (US \$154 in USA, Canada and Mexico) for institutions (print and electronic); $£ 82$ (US \$139) for institutions (electronic only); $£ 26$ (US \$43) for individuals ordering direct from the publishers and certifying that the journal is for their personal use (print only). EU subscribers (outside the UK) who are not registered for VAT should add VAT at their country's rate. VAT registered members should provide their VAT registration number. Japanese prices for institutions (including ASP delivery) are available from Kinokuniya Company Ltd, P.O. Box 55, Chitose, Tokyo 156, Japan.

Orders, which must be accompanied by payment, may be sent to a bookseller, subscription agent or direct to the publisher: Cambridge University Press, The Edinburgh Building, Shaftesbury Road, Cambridge CB2 8RU; or in the USA, Canada and Mexico: Cambridge University Press, Journals Fulfillment Department, 100 Brook Hill Drive, West Nyack, New York 10994-2133. Periodicals postage paid at New York, NY and at additional mailing offices.

\section{Copying}

This journal is registered with the Copyright Clearance Center, 222 Rosewood Drive, Danvers, MA 01923, USA. Organizations in the USA who are also registered with the C.C.C. may therefore copy material (beyond the limits permitted by sections 107 and 108 of U.S. Copyright law) subject to payment to the C.C.C of the per copy fee of $\$ 12$. This consent does not extend to multiple copying for promotional or commercial purposes. Code 0040-2982/2014 \$12. ISI Tear Sheet Service, 3501 Market Street, Philadelphia, PA 19104, USA, is authorized to supply single copies of separate articles for private use only. Organizations authorized by the Copyright Licensing Agency may also copy, material subject to the usual conditions. For all other use, permission should be sought from Cambridge or from the American Branch of Cambridge University Press.

This journal is included in the Cambridge Journals Online service which can be found at journals.cambridge.org.

This journal issue has been printed on FSC-certified paper and cover board. FSC is an independent, non-governmental, not-for-profit organization established to promote the responsible management of the world's forests. Please see www.fsc.org for information.

Printed in the UK by Bell \& Bain.

cover design: Studio Isabelle Vigier

(C) Cambridge University Press 2014 


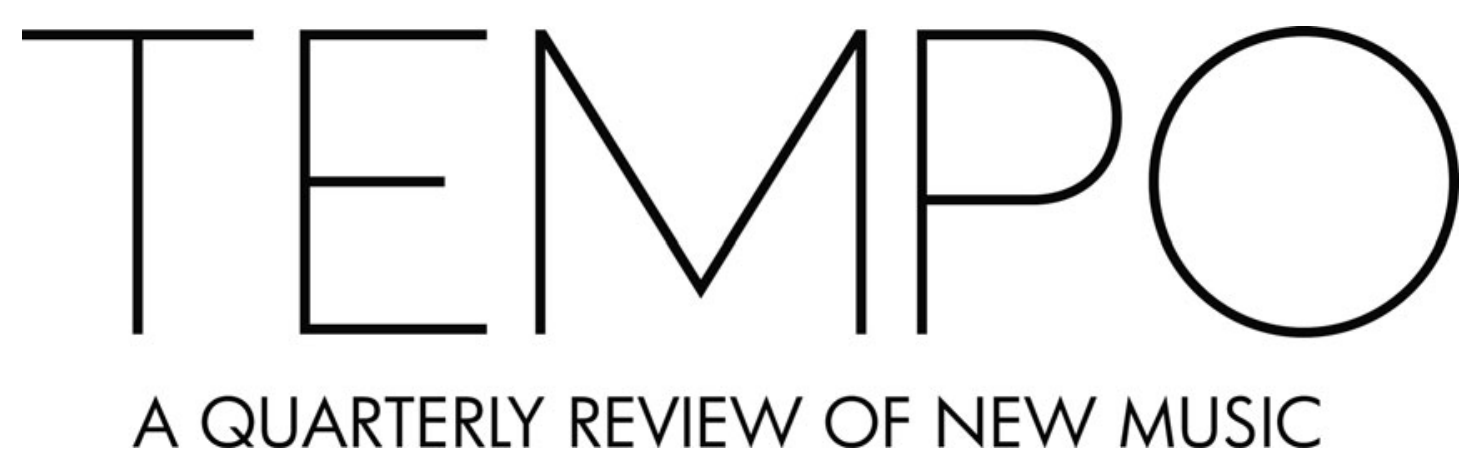

EDITOR Bob Gilmore / REVIEWS EDITOR Juliet Fraser

VOLUME 68 NO. 269 JULY 2014

3 EDITORIAL: VERY HEAVEN

ARTICLES

6 OPENING OFFER OR CONTRACTUAL OBLIGATION? ON THE PRESCRIPTIVE FUNCTION OF NOTATION IN MUSIC TODAY

Christopher Fox

20 JOANNA BAILIE: STRANGE PARALLEL MUSIC

Stephanie Power

30 RIGHT AND WRONG: THE MUSIC OF ANDREW HAMILTON

Donal Sarsfield

42 PERFORMING THE PATRON: BETTY FREEMAN AND THE

AVANT-GARDE Jake Johnson

50 ALONG THE GRAIN: THE MUSIC OF CASSANDRA MILLER

James Weeks

FIRST PERFORMANCES

65 'The New Experimentalists' Cameron Graham

66 BBCSO plays Murail, Dufourt and Grisey Liam Cagney

67 Howard Skempton/Matthew Harris 'Field Notes'

Peter Reynolds

69 Peter Maxwell Davies Tenth Symphony William Cole

70 James MacMillan round-up Paul Conway

72 Bangor New Music Festival and INTER/actions

Stephanie Power

74 Festival Présences Liam Cagney

76 Ultraschall Berlin Andrew Noble

CDs AND DVDs

80 James Erber 'The Traces Cycle' Arnold Whittall

81 Oliver Coates Adam Harper

82 Robert Fokkens Edward Venn

83 Matthew Shlomowitz/Peter Ablinger Lawrence Dunn

84 Håkon Stene Lauren Redhead

86 Fritzi und Heidel, Zwerm and Nico Couck Louise Gray

88 Michael Finnissy Michael Hooper 
BOOKS

90 Noise In and As Music Seth Ayyaz Bhunnoo

92 R. Murray Schafer Graham Flett

94 Sergey and Lina Prokofiev Martin Anderson

96 The Engaged Musician Samuel Vriezen

PROFILE

100 Winrich Hopp

102 CONTRIBUTORS 